\title{
How to Understand Industrial Internship Program for Preparing Employability Skills of Vocational Students in Indonesia
}

\author{
$1^{\text {st }}$ Didik Nurhadi \\ Graduate School of Technological \& Vocational Education \\ National Yunlin University of Science and Technology \\ Douliou, Taiwan \\ didiknurhadi.um@gmail.com
}

\author{
$2^{\text {nd }}$ Siti Zahro \\ Graduate School of Technological \& Vocational Education \\ National Yunlin University of Science and Technology \\ Douliou, Taiwan \\ sitizahrovivi@gmail.com
}

\author{
$3^{\text {rd }}$ Nyan-Myau Lyau \\ Graduate School of Technological \& Vocational Education \\ National Yunlin University of Science and Technology \\ Douliou, Taiwan \\ lyaunm@yuntech.edu.tw
}

\begin{abstract}
Industrial internship program (IIP) has been widely recognized in many developed countries. This program has shown a contribution to the improvement of labor market outcomes for their country's economic development. This is demonstrated by the quality of job performance of vocational education graduates in the workplace. One of IIP successes is because it has implemented effectively by vocational education and industries supported by the government to provide employability skills to their students. Indonesia as one of the developing countries has also implemented IIP in vocational education both at the levels of higher education and high school, but this program indicated that the contribution of IIP was very minimal to provide work experience directly to the students. This is happening because of different understanding between education and industry how to develop IIP for preparing students' employability skills. Furthermore, to solve this issue, an understanding to develop sustainable IIP in Indonesia will be explained in this paper.
\end{abstract}

Keywords-internship program; vocational education; industrial patner; emplyability skills

\section{INTRODUCTION}

Industrial internship program plays a pivotal role in preparing employability skills of engineering students to work in the job world [1]. This program can give vocational students certain skills needed by industries that this is not given in the classroom effectively [2-4]. They need to prepare for their career; it is not only be prepared in academic courses but also it is needed to prepare for other things, especially in their future careers. Because industries in Indonesia believe that vocational students don't have practical skills, experience, adaptability skills, and others needed real-world in the work market [5-6]. Therefore, this attracts broad attention from educational fields and business world to ensure their career successes and industrial growth.
In Indonesia, according to World Economic Forum [7], the efficiency of labor market in Indonesia indicates the lack of global competitiveness due to graduates of higher education institutions no relevant with the need of labor market. This happened by several reasons. First, the evaluation of industrial internship program mentioned that the program internship implementation for college students have cons traints on as pects of the role of internship program coordinator, students' workability, supervis or roles in monitoring and supervising internship program, benefits of learning and teaching in the industry, model of internship program implementation, and internship program evaluation. While constraints on aspects of the internship results are the skill mastery and the standards of graduation requirements [8]. Second, Fransiska, Yudana, and Natajaya [9] also mentioned that the contribution of industrial internship practices on the students' competence is average 5.4 percent in Indonesia. Third, this occurred by misunderstanding about employability skill preparation between vocational education institutions and partner industries in the industrial internship program [10]. This data is also significant with an increase in unemployment of college graduates over the last three years by Indonesian Statistics [11].

To finish these is sues, authors try to make an understanding for industrial internship program development for preparing employability skills of vocational students in Indonesia. The purposes are link and match in industrial internship program happened between vocational education institution and partner industries in Indonesia. So that, vocational education graduates have relevance competencies to compete in the national and global market.

\section{IIP IN INDONESIA}

In Indonesia, industrial internship program are merely between industries and internship-undertaking students. 
Industries will appoint an instructor to supervise the students. Engineering educational institutions are not directly involved in this program, and only serve as monitors [12-13].

Subsequently, the students have to report the result of the internship program in accordance with the student internship module devised by each major of engineering education. Generally, the module explains what students have to report, format of the report, and assessment process of the student internship program. It is the duty of the instructors from industry and college to make assessment of the program and make scores [14].

Unfortunately, until recently, internship modules have not explained effective strategies to run internship programs regularly. The regular internship program is believed to enable engineering institutions to develop professional technical skills of vocationalstudents and test their competences explicitly and implicitly under agreement between vocational education institutions and industries. This poor condition leads to ineffective implementation of the program and stimulation of activities irrelevant to the purpose of the internship program.

According to the research by Sintawati and Sudjimat [8], the problem with strategies forms an obstacle hindering the establishment of internship programs, which results in students' poor skills. Besides, educational institutions' not running the internship program seriously also contributes to the fact that the establishment of the program fails to fulfill the intended target. Nederstigt and Mulder [15] stated that in Indonesia, internship implementation has minor contribution to the development of students' competences (5.4\%). The data is in alignment with the fact that the number of unemployed graduates of higher educational institutions has significantly increased since the last three years [11].

This illustrates that challenges in internship programs in Indonesia include (1) engineering education's understanding the need of employability skills in industries, (2) its preparing internship students according to the demand of global labor market, (3) its planning the program together with industrial leaders, (4) its evaluating the implementation of the program together with industry to devise effective strategies to develop students' professional skills, and (5) its motivating internship instructors and supervisors to enhance their performance by giving them incentives for their welfare. It is essential that all of the challenges be met to provide engineering students with employability skills relevant to academic and technical requirements of industry.

Based on this condition, considering that the internship program is highly instrumental in providing students with professional skills as global labor market requires, Warinda [1] and OECD [16] suggested that there must be integration between educational institutions and industries leaders in implementing the program. The program helps students have special skills in work places which may not be taught effectively in classes [2-4]. In addition to doing well in each of their academic subjects, students need to prepare themselves for their future careers as well. They may undertake preparatory programs of real works to have direct work experiences and professional skills [5-6]. Hence, vocational educational institution together with industrial leaders should pay total attention to this program to ensure students' successful careers and industrial growth for Indonesia economic development.

\section{HOW TO IMPROVE SUST AINABLE IIP IN INDONESIA}

The condition from the industrial internship program (IIP) in Indonesia needs to be improved to produce IIP outcomes as expected by the global labor market. The outputs are to equip engineering students with employability skills professionally in accordance with the standardized and expected by industries. An industrial internship program needs to be jointly planned between engineering education institutions and industries to establish a sustainability industrial internship program. The implementation also requires being supported by government policies about the development of IIP organized by higher educational institutions and industrial partners. The involvement of three institutions, engineering education, industry, and the government is known as a triple helix model collaboration. Further Figure 1 illustrated a model of sustainable IIP improvement between vocational education institutions and industries with the full support of the government.

Fig. 1. Sustainable IIP improvement in industries for vocational education

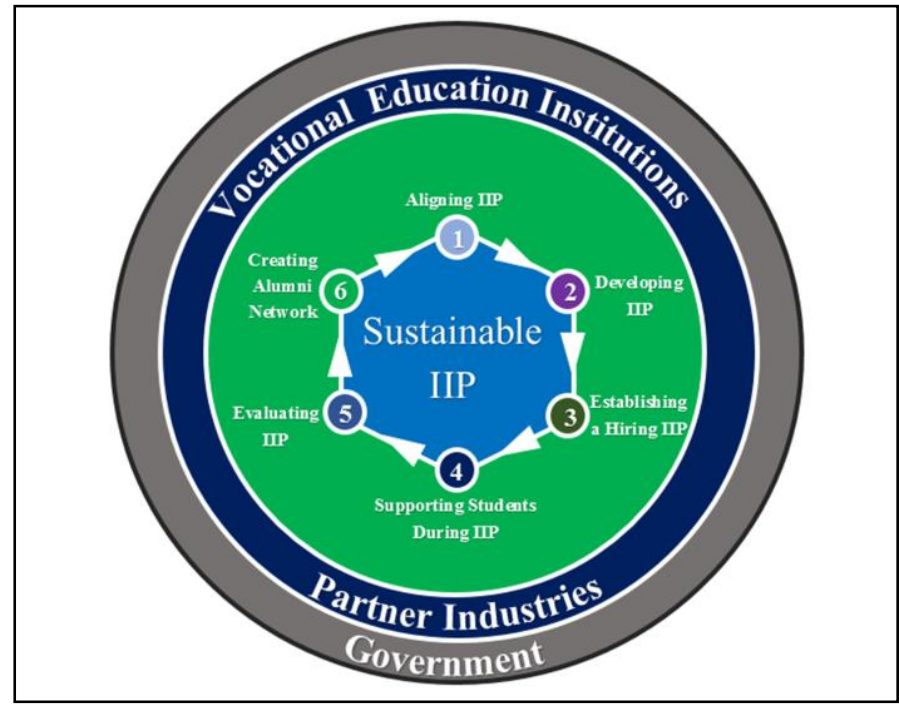

institutions in Indonesia

On Figure 1 showed that sustainable IIP improvement consists of six stages as a cycle set, aligning industrial internship program (IIP), developing industrial internship program (IIP), establishing a hiring of industrial internship program (IIP), supporting students during industrial internship program (IIP), evaluating industrial internship program (IIP), and creating alumni network. They should be undertaken in an integrated manner between the engineering education institutions and industries. Further explanation of the six stages was as follows: 


\section{A. Step 1: Aligning IIP}

This stage is to improve sustainable IIP planning. Based on Rex and Stoffel [18], four steps that required to improve it are set goals and priorities for IIP, determine IIP size and type, assess funding available of IIP, and draft a guiding of IIP document.

This is a crucial step in IIP improvement to align goals and priorities of IIP with strategy planning conducted by the vocationaleducation institution. This needs to give good access to find resources for financial funding, to make good communication among administrators, teachers, vocational education leaders, and industrial leaders. Then, these can influence sustainable strategies and efforts to improve course contents regarding teaching and learning in the vocational education institution.

Furthermore, determining IIP size and scopes is a crucial factor in step 1. The IIP size is determined by the institution and participants. The institution level determines the number of participants that will join in this program. While participants are determined by scopes of IIP conducted by vocational education institution and industries.

Assessing funding available is a crucial factor to predict the budget needed for creating the successful IIP in education institutions. [17]. When creating a budget, according to True [13], the expenses that should be considered are internship compensation, internship, program management, mentorship, academic, supplies, professional development, and associated program costs.

To make a draft of the document of IIP guide, a document draft should be made. The outlines include IIP missions, IIP functions, and SIIP structures. These will help to promote understanding of goals for the vocational education institution, vocational students, and potential financial supported this program. In drafting a document of SIIP guide, Rex and Stoffel [18] give six factors as considerations to do it. The first factor is vision and mission of IIP that describe IIP purposes and SIIP goals. The second factor is the IIP structure that explains who can manage IIP and how to manage IIP. The third factor is roles and responsibilities of IIP regarding expectations to accept vocational students in the IIP. The fourth factor is SIIP participants. This is to make some requirements for vocational students that can join in the IIP. The fifth factor is an application process that will explain how to apply IIP, how to evaluate IIP applications, and how to complete the application process. The last factor is a financial budget of IIP that will describe how to manage Sustainable IIP expenses including compensation and program sustain.

\section{B. Step 2: Developing IIP}

With developing the IIP project systematically and integrated between vocational education institution and industry, vocational students will interest to follow IIP during project implementation. This step gives early background to develop ideas for new IIP projects in order to improve the quality of SIIP project ideas and to create a model of IIP project submission [19]. This can be done through sourcing project ideas from industries and be contextualizing project ideas.

\section{Step 3: Establishing a Hiring for IIP}

For establishing a recruitment process for IIP participants, it should be carried out by vocational education institution with involving all departments to know their needs to prepare their students to fulfill the demand manpower in the global labor market. According to Rex and Stoffel [18], several basic steps that are considered when structuring a process for hiring sustainability internship including articulating program ideas, developing criteria to recruit participants, structuring the recruitment process, making application and evaluation system, recruiting students, selecting the internship, and offering the job.

\section{Step 4: Supporting Students during IIP}

Several research results mentioned that for giving opportunities for vocational students to improve IIP on their internships, there need to support the IIP framework clearly [20-21]. This needs to provide resources in each field. Furthermore, there focus on improvement and distribution of IIP tutor responsibilities among vocational education leaders, development teaching content relevantly and sustainability, implementation of leadership management, organizational management, and encouragement of management of students' projects effectively and efficiently [18]. Several things that need to be done to support engineering students during the internship in the industry are developing good mentors and providing foundational knowledge for engineering students.

\section{E. Step 5: Evaluating IIP}

Measuring IIP success is an important to conduct it. The aims are to improve students' skills and outcomes of overall IIP steps, to increase support from vocational education institution leaders, and to access potential financial support from outside [22-25]. Then, to evaluate IIP success is not easy to conduct by IIP management [26]. Several strategies for as sessing programs includes articulating IIP goals, developing metrics to measure the IIP success based on IIP goals, assessing data access from vocational education institution for each IIP metrics, developing a system to track data, making a baseline of IIP measurement, and assessing IIP data [27].

\section{F. Step 6: Creating Alumni Network}

Alumni of IIP program constitute big assets to develop IIP sustainability. Effective IIP will be showed partially by student success after finishing IIP. Furthermore, IIP alumni can help leaders of vocational education institution to improve networking opportunities in the industries where they work in order to implement IIP sustainability in vocational education institution [28].

\section{CONCLUSION}

To understand poor employability skills of education graduates in current condition, vocational education institutions and partner industries in Indonesia need to make improvements for the internship program management through a sustainable IIP. This development requires support from the government as a policymaker at the country level about the program. SIIP will improve existing approaches effectively from preparation, 
implementation, and evaluation. The sustain able IIP consists of four stages, aligning IIP, developing IIP, establishing a hiring of IIP, supporting students during IIP, evaluating IIP, and creating the alumni network that works on an ongoing basis .

Suggestions recommended for the upgrading of sustainable IIP for vocational students in Indonesia including (1) Vocational education institutions need to make process improvements for the implementation of the current industrial internship program. The commitment of leaders and policymakers at the level of educational institutions is crucial to realize the improvement of this program as expected by industries. (2) The partner industries need to welcome the upgrading of the sustainable industrial internship program planned by the engineering education institution. They need to be open and committed to determining the components associated with the development of the program. (3) The government needs to issue a policy on the internship program development in higher education that integrated with industries. The government should facilitate the establishment of a sustainable industrial internship program between engineering education institutions and industries. These facilities can be carried out through joint discussion and funding support to realize this program.

\section{REFERENCES}

[1] T. Warinda, “Accounting students' evaluation of internship experiences from a skills perspective," International Journal of Asian Social Science, vol. 3, iss. 3, pp. 783-799, 2013.

[2] T. Bisoux, “Joining forces," Biz Ed, pp. 48-55, November 2007.

[3] B. Z. Posner, "Be Leaders: On leadership,"Biz Ed., vol. 7, no. 3, pp. 2627, Mei 2008.

[4] E. B. Kim, K. Kim, \& M. Bzullak, "A survey of internship programs for management undergraduates in AACSB-accredited institutions," International Journal of Educational Management, vol. 26, iss. 7, pp. 696-709, 2012.

[5] C. A. Kelley, \& R. M. Gaedeke, "Student and employer evaluation of hiring criteria for entry-level marketing positions," Journal of Marketing Education, vol. 12, iss. 3, pp. 64-71, December 1990.

[6] C. A. Kelly, \& C. Bridges, "Introducing professional and career development skills in the marketing curriculum," Journal of Marketing Education, vol. 27, iss. 3, pp. 21-28, December 2005.

[7] World Economic Forum, Insight Report: The Global Competitiveness Report 2016-2017. Geneva: World Economic Forum, 2015.

[8] E. Sintawati, \& D. A. Sudjimat, "Evaluasi program praktik industri mahasiswa program studi tata busana jurusan teknologi industri fakult as teknik Universitas Negeri Malang berdasarkan model CIPP,” Teknologi dan Kejuruan, vol. 37, no. 1, pp. 49-64, 2014.

[9] M. Fransiska, I. M. Yudana, \& N. Natajaya, "Kontribusi praktek kerja industri, bimbingan karir kejuruan, dan ekspektasi karir terhadap kompetensi kejuruan (Studi pada mahasiswa jurusan tata boga Undhira Bali)," e-Journal Program Pascasarjana Universitas Pendidikan Ganesha, vol. 4, pp. 1-10, 2013.
[10] D. Nurhadi, A Survey on the Internship Program for Engineering Education in Indonesia (Doctoral Dissertation). T aiwan: National Yunlin University of Science and Technology, 2017.

[11] Indonesian Statistics, Labor Force Situation in Indonesia. Jakarta: Indonesian Statistics, 2015.

[12] J. McKimm, C. Jollie, \& M. Hatter, Mentoring: Theory and Practice. London: NHSE, 2007.

[13] M. True, Starting and maintaining a quality internship program. Harrisburg, PA: Technology Council of Central Pennsylvania, 2002.

[14] Mechanical Engineering Team, Internship Guide for the Mechanical Engineering Education Student. Malang, Indonesia: State University of Malang, 2015.

[15] W. Nederstigt, \& M. Mulder, Competence Based Education in Indonesia: Evaluating the Matrix of Competence-Based Education in Indonesian higher education. Netherlands: Wageningen University, 2011.

[16] OECD, Education in Indonesia: Rising to the Challenge. Paris: OECD Publishing, 2015.

[17] PM4DEV, Project Management for Development Organizations: A Methodology to Manage Development Projects for International Humanit arian Assistance and Relief Organizations. PM4DEV (Project Management for Development Organizations), 2015.

[18] E. Rex, \& J. Stoffel, Guide to Creating \& Managing Sustainability Internship Programs. Denver, CO: Association for the Advancement of Sustainability in Higher Education, 2014.

[19] V. Fayolle, S. Odianose, \& M. Soanes, GCF Project Toolkit 2017. Guide to Develop a Project Proposal for the Green Climate Fund (GCF). Acclimatise, London: Acclimatise Group Limited, 2017.

[20] J. Santana, 2017 Access Tech Internship Program: Preparing the Next Generation Of Technology Leaders. New York: New York On Tech, 2017.

[21] K. Tremblay, D. Lalancette, \& D. Roseveare, Assessment of Higher Education Learning Outcomes: Feasibility Study Report. Volume 1 Design and Implementation. Paris: OECD, 2012.

[22] Center for Substance Abuse Treatment, Substance Abuse: Administrative Issues in Out patient T reatment. Treatment Improvement Protocol (TIP) Series 46. DHHS Publication No. (SMA) 06-4151. Rockville, MD: Substance Abuse and Mental Health Services Administration, 2006.

[23] D. Jenkins, \& O. Rodriguez, "Access and success with less: Improving productivity in broad-access postsecondary institutions," The Future of children, vol. 23, no. 1, pp. 187-209, Sping 2013.

[24] E. Montenegro, \& N. A. Jankowski, Focused on What Matters: Assessment of Student Learning Outcomes at Minority-Serving Institutions. Urbana, IL: University of Illinois and Indiana University, National Institute for Learning Outcomes Assessment, 2015.

[25] J. H. Schuh, \& A. M. Gansemer-Topf, The Role of Student Afneithers in Student Learning Assessment. Champaign, IL: National Institute for Learning Outcomes Assessment (NILOA), 2010.

[26] F. O. Omotayo, "Knowledge Management as an important tool in organisational management: A review of literature," Library Philosophy and Practice, no. 1238, pp. 1-23, October 2015.

[27] R. Bowlby, "Living the future: Organizational performance assessment," Journal of Library Administration, vol. 52, iss. 6-7, pp. 626-652. October 2012.

[28] S. Kinash, "8 ways to enhance your students' graduate employability," Teaching the Bond Way, iss. 2, pp. 1-14, January 2015. 